JURNAL NOMINAL / VOLUME VII NOMOR 1 / TAHUN 2018

\title{
PENGARUH PENGETAHUAN KEUANGAN, SIKAP KEUANGAN, DAN KEPRIBADIAN TERHADAP PERILAKU MANAJEMEN KEUANGAN PADA PELAKU UMKM SENTRA KERAJINAN BATIK KABUPATEN BANTUL
}

\begin{abstract}
THE INFLUENCE OF FINANCIAL KNOWLEDGE, FINANCIAL ATTITUDE, AND PERSONALITY TOWARDS FINANCIAL MANAGEMENT BEHAVIOR ON SMALL MEDIUM ENTERPRISES AT BATIK CRAFT OF BANTUL REGENCY
\end{abstract}

\author{
Iklima Humaira \\ Prodi Akuntansi Universitas Negeri Yogyakarta \\ iklimahumaira6@gmail.com \\ Endra Murti Sagoro \\ Staf Pengajar Jurusan Pendidikan Akuntansi Universitas Negeri Yogyakarta
}

\begin{abstract}
Abstrak: Pengaruh Pengetahuan Keuangan, Sikap Keuangan, dan Kepribadian Terhadap Perilaku Manajemen Keuangan pada Pelaku UMKM Sentra Kerajinan Batik Kabupaten Bantul

Penelitian ini bertujuan untuk mengetahui (1) pengaruh Pengetahuan Keuangan terhadap Perilaku Manajemen Keuangan pada pelaku UMKM Sentra Kerajinan Batik Kab.Bantul, (2) pengaruh Sikap Keuangan terhadap Perilaku Manajemen Keuangan pada Pelaku UMKM Sentra Kerajinan Batik Kab.Bantul, (3) pengaruh Kepribadian terhadap Perilaku Manajemen Keuangan pada Pelaku UMKM Sentra Kerajinan Batik Kab.Bantul, (4) dan pengaruh Pengetahuan Keuangan, Sikap Keuangan, dan Kepribadian terhadap Perilaku Manajemen Keuangan pada Pelaku UMKM Sentra Kerajinan Batik Kab.Bantul. Subjek penelitian ini adalah seluruh pemilik UMKM Sentra Kerajinan Batik Kab.Bantul Sebanyak 37 UMKM. Uji prasyarat analisis meliputi uji linearitas, uji multikolinearitas dan uji heteroskedastisitas. Teknik analisis data yang digunakan adalah analisis regresi linier sederhana dan analisis regresi linier berganda. Hasil penelitian menunjukkan bahwa (1) terdapat pengaruh positif Pengetahuan Keuangan terhadap Perilaku Manajemen Keuangan pada pelaku UMKM Sentra Kerajinan Batik Kab.Bantul, (2) terdapat pengaruh positif Sikap Keuangan terhadap Perilaku Manajemen Keuangan pada pelaku UMKM Sentra Kerajinan Batik Kab.Bantul, (3) terdapat pengaruh positif Kepribadian terhadap Perilaku Manajemen Keuangan pada pelaku UMKM Sentra Kerajinan Batik Kab.Bantul, (4) terdapat pengaruh positif Pengetahuan Keuangan, Sikap Keuangan, dan Kepribadian terhadap Perilaku Manajemen Keuangan pada pelaku UMKM Sentra Kerajinan Batik Kab.Bantul.
\end{abstract}

Kata Kunci: Pengetahuan Keuangan, Sikap Keuangan, Kepribadian, Perilaku Manajemen Keuangan

Abstract: The Influence of Financial Knowledge, Financial Attitude, and Personality towards Financial Management Behavior on Small Medium Enterprises at Batik Craft of Bantul Regency

The purpose of this study is to determine (1) the influence of financial knowledge towards financial management behavior on SMEs at Batik Craft Center of Bantul, (2) the influence of financial attitude towards financial management behavior on SMEs at Batik Craft Center of Bantul, (3) the influence of personality towards financial management behavior on SMEs at Batik Craft Center of Bantul, (4) the influence of financial knowledge, financial attitude, and personality towards financial management behavior on SMEs at Batik Craft Center of Bantul. This research subject is the whole business of SMEs at Batik Craft Center of Bantul, total of 37 SMEs. Analysis prerequisite test included linearty test, multicolinearity test, and heteroscedasticity test. The data analysis technique used a simple and multiple linear regression analysis. The result of this study showed that: (1) there was positive influence of financial knowledge towards financial management behavior on SMEs at Batik Craft Center of Bantul, (2) there was positive influence of financial attitude towards financial management behavior on SMEs at Batik Craft Center of Bantul, (3) there was positive influence of personality towards financial management behavior on SMEs at Batik Craft Center of Bantul, (4) there was a positive influence of financial knowledge, financial attitude, and personality towards financial management behavior on SMEs at Batik Craft Center of Bantul. 
JURNAL NOMINAL / VOLUME VII NOMOR 1 / TAHUN 2018

Keywords: Financial Knowledge, Financial Attitude, Personality, Financial Manajemen Behavior.

\section{PENDAHULUAN}

Kontribusi Usaha Mikro, Kecil dan Menengah (UMKM) di Indonesia tidak perlu diragukan lagi. Berdasar informasi dari Kementerian Bagian Data - Biro Perencanaan Kementrian Negara Koperasi dan UKM Republik Indonesia, UMKM memberi berbagai jenis kontribusi, diantaranya adalah kontribusi UMKM terhadap penciptaan investasi nasional, Kontribusi UMKM tehadap Produk Domestik Bruto (PDB) Nasional, kontribusi UMKM dalam penyerapan tenaga kerja nasional, dan kontribusi UMKM terhadap penciptaan devisa nasional. Secara singkat dapat disimpulkan bahwa UMKM merupakan pilar utama (soko guru) perekonomian Indonesia. Hal tersebut menunjukkan bagaimana peran UMKM sangat dominan dalam pertumbuhan ekonomi Indonesia. Sehingga pemberdayaan UMKM merupakan sesuatu yang penting dalam upaya meningkatkan pertumbuhan perekonomian di Indonesia. Sumbangsih UMKM terhadap PDB menjadikan indikator pentingnya UMKM dalam peningkatan pertumbuhan perekonomian di Indonesia. Eksistensi dan kinerja UMKM yang semakin menggeliat tersebut bukan tanpa masalah dan kendala. Terdapat beberapa masalah diantaranya dalam perilaku manajemen keuangan para pelaku UMKM.

Perilaku manajemen keuangan dianggap sebagai salah satu konsep penting pada disiplin ilmu keuangan. Banyak definisi yang diberikan sehubungan dengan konsep ini, misalnya, Horne dan Wachowicz (2002) dalam Mien dan Thao (2015) mengusulkan perilaku manajemen keuangan sebagai penentuan, akuisisi, alokasi, dan pemanfaatan sumber daya keuangan. Sedangkan secara keseluruhan Weston dan Brigham (1981) dalam Mien dan Thao (2015) menggambarkan perilaku manajemen keuangan sebagai suatu pengambilan keputusan keuangan, harmonisasi motif individu dan tujuan perusahaan. Sedangkan menurut Mien dan Thao (2015) manajemen keuangan berkaitan dengan efektivitas manajemen dana.

Terdapat beberapa masalah pada UMKM yang menjadi perhatian, diantaranya berkaitan dengan perilaku manajemen keuangan yaitu permasalahan pengetahuan keuangan yang dimiliki. Pengetahuan keuangan terdiri dari keterampilan keuangan dan penguasaan alat keuangan. Ida dan Dwinta (2010) menjelaskan keterampilan keuangan sebagai sebuah teknik untuk membuat keputusan dalam perilaku 


\section{JURNAL NOMINAL / VOLUME VII NOMOR 1 / TAHUN 2018}

manajemen keuangan, seperti menyiapkan sebuah anggaran, memilih investasi, memilih rencana asuransi, dan menggunakan kredit adalah contoh dari keterampilan keuangan. Sedangkan alat keuangan adalah sarana yang digunakan dalam pembuatan keputusan manajemen keuangan seperti cek, kartu kredit, dan kartu debit.

Permasalahan dalam hal keterampilan keuangan yang dialami para pelaku UMKM utamanya adalah dalam hal menyiapkan anggaran. Kebanyakan pelaku UMKM tidak pernah menyiapkan anggaran keuangan dalam manajemen usahanya, terbukti berdasarkan survei yang dilakukan Raharjo dan Wirjono (2012), kebanyakan pelaku UMKM tidak pernah membuat pembukuan apapun terkait manajemen usahanya. Seharusnya pelaku UMKM membuat pembukuan terkait perencanaan anggaran, pelaksanaan, dan pengendalian dalam keuangannya. Namun fakta yang ditemukan adalah kesadaran pelaku UMKM untuk membuat pembukuan untuk manajemen keuangan usahanya masih sangat rendah. Penyebab rendahnya kesadaran pelaku UMKM dalam membuat perencanaan angaran dikarenakan oleh pemikiran pelaku UMKM bahwa perencanaan anggaran tidak penting dan dapat diatur dengan mudah dan tidak ada dampak buruk bagi keberlangsungan usaha mereka meskipun pelaku UMKM tidak melakukan perencanaan anggaran.

Permasalahan keterampilan keuangan yang selanjutnya adalah dalam hal investasi. Tidak banyak pelaku UMKM yang terjun ke dunia investasi. Berdasarkan wawancara yang telah dilakukan, penyebab rendahnya minat pelaku UMKM untuk berinvestasi dikarenakan para pelaku UMKM tidak cukup paham dan bahkan sama sekali tidak tahu mengenai apa itu investasi. Sehingga para pelaku UMKM memilih tidak berinvestasi. Hal tersebut mengindikasikan bahwa pengetahuan pelaku UMKM tentang investasi masih sangat rendah.

Permasalahan keterampilan keuangan tidak hanya dalam hal anggaran dan investasi saja, dalam hal kredit juga para pelau UMKM juga mengalami kendala. Pengetahuan mengenai kredit para pelaku UMKM masih sangat rendah. Pelaku UMKM tidak begitu paham faktor-faktor yang memengaruhi kelayakan kredit, sehingga sulit bagi pelaku UMKM untuk memperoleh tambahan modal. Selain itu, banyak pelaku UMKM yang tidak melakukan berbagai pertimbangan saat mengajukan kredit, seperti pertimbangan tingkat bunga pinjaman dan jangka waktu pinjaman. Seharusnya para pelaku UMKM mampu mempertimbangkan berbagai hal pada saat akan mengajukan kredit agar dapat menggunakan kredit secara bijaksana. 


\section{JURNAL NOMINAL / VOLUME VII NOMOR 1 / TAHUN 2018}

Secara umum, kurangnya pengetahuan keuangan dalam hal keterampilan keuangan diatas diakibatkan oleh pendidikan. Pengetahuan keuangan dapat diperoleh dari pendidikan formal dan sumber-sumber informal. Pendidikan formal ini seperti program sekolah tinggi atau kuliah, seminar, dan kelas pelatihan di luar sekolah. Sedangkan sumber-sumber informal dapat diperoleh dari lingkungan sekitar, seperti dari orang tua, teman, dan rekan kerja, maupun yang berasal dari pengalaman sendiri. Pinasti (2007) menyatakan bahwa para pengusaha kecil tidak memiliki pengetahuan akuntansi, dan banyak diantara mereka yang belum memahami pentingnya pencatatan dan pembukuan bagi kelangsungan usaha. Apabila pelaku UMKM memiliki pengetahuan akuntansi yang baik, sudah pasti pelaku UMKM memiliki keterampilan keuangan yang baik pula. Berdasarkan uraian tersebut dapat dikatakan pengetahuan keuangan para pelaku UMKM sangat buruk.

Terdapat masalah lain yang mempengaruhi perilaku manajemen keuangan yang dimiliki oleh para pelaku UMKM, yaitu masalah mengenai sikap keuangan yang dimiliki. Kebanyakan pelaku UMKM tidak memiliki sikap yang buruk mengenai keuangan, ditandai dengan rendahnya motivasi untuk terus meningkatkan kemampuannya dalam mengelola keuangan usahanya, padahal motivasi untuk terus meningkatkan kemampuan dalam manajemen keuangan sangat penting. Buruknya sikap keuangan yang dimiliki para pelaku UMKM juga ditandai dengan pemikiran yang mudah merasa puas dengan kinerja yang ada dan belum berfikir untuk melakukan peningkatan kemampuan dibidang manajemen keuangan karena sebagian pelaku usaha merasa kinerjanya sudah cukup baik dan usahanya tetap berjalan dengan lancar dan tanpa kendala meskipun pelaku UMKM tidak membuat perencanaan anggaran dan pengendalian terhadap keuangan. Sikap tersebut apabila apabila dibiarkan akan membuat kinerja UMKM menurun dan tidak mampu bersaing secara kompetitif di pasar. Seperti yang diungkapkan (Kiryanto, dkk. 2001), bahwa seorang pelaku usaha memerlukan motivasi kerja untuk membangun usahanya agar semakin berkembang. Motivasi kerja yang dimaksud dapat berupa motivasi untuk terus meningkatkan kemampuan diri dalam mengelola keuangan.

Para pengguna akuntansi khususnya dalam hal ini pelaku UMKM sudah seharusnya lebih memperhatikan manajemen keuangan pada usaha yang dijalankannya mengingat manfaat dari pengetahuan keuangan dan sikap keuangan yang begitu 


\section{JURNAL NOMINAL / VOLUME VII NOMOR 1 / TAHUN 2018}

besar bagi keberlangsungan usahanya. Selain itu, menyiapkan anggaran dapat menjadi modal dasar bagi UMKM untuk pengambilan keputusan-keputusan dalam pengelolahan usaha kecil, antara lain keputusan pengembangan pasar, pengembangan harga, dan dalam hubungannya dengan dan kreditur. Menyiapkan anggaran juga dapat digunakan dalam rangka menyusun berbagai proyeksi, misalnya proyeksi kebutuhan uang kas di masa yang akan datang, mengontrol biaya, mengukur dan meningkatkan produktivitas dan memberikan dukungan terhadap proses produksi.

Berbagai permasalahan yang dialami para pelaku UMKM mencerminkan buruknya pengetahuan keuangan dan sikap keuangan yang dimiliki para pelaku UMKM yang nantinya akan mempengaruhi perilaku manajemen keuangan yang dimiliki. Banyak upaya dilakukan untuk mengungkapkan faktor apa saja yang mempengaruhi rendahnya perilaku manajemen keuangan. Salah satu penelitian yang mengungkapkan faktor-faktor yang mempengaruhi perilaku manajemen keuangan adalah penelitian yang dilakukan oleh Mien dan Thao (2015) yang berjudul Factors Affecting Personal Financial Management Behaviors: Evidence from Vietnam. Penelitian ini menyatakan faktor-faktor yang mempengaruhi perilaku manajemen keuangan pada generasi muda usia 19-30 tahun antara lain sikap keuangan, pengetahuan keuangan, dan locus of control.

Di Indonesia sendiri telah terdapat penelitian serupa salah satunya oleh Ida dan Dwinta (2010) dalam penelitiannya mengungkapkan bahwa terdapat beberapa faktor yang berpengaruh terhadap perilaku manajemen keuangan seperti locus of control, pengetahuan keuangan, dan pendapatan. Kemudian Tarry Novita Maharani (2016) juga melakukan penelitian serupa dan mengungkapkan bahwa faktor-faktor yang mempengaruhi perilaku manajemen keuangan yaitu literasi keuangan pribadi dan sikap keuangan.

Terdapat banyak variabel yang dapat mempengaruhi perilaku manajemen keuangan, salah satunya adalah pengetahuan keuangan. Kholilah dan Iramani (2013) mendeskripsikan pengetahuan keuangan sebagai penguasaan seseorang atas berbagai hal tentang dunia keuangan alat keuangan dan keterampilan keuangan. Individu dengan pengetahuan keuangan yang memadai akan memiliki perilaku manajemen keuangan yang lebih baik, seperti membayar tagihan tepat waktu, melakukan pembukuan terhadap pengeluaran yang dilakukan setiap bulan, dan memiliki cadangan dana untuk kondisi darurat (Yulianti dan Silvy, 2013).

Variabel selanjutnya yang dapat memengaruhi perilaku manajemen keuangan 


\section{JURNAL NOMINAL / VOLUME VII NOMOR 1 / TAHUN 2018}

adalah sikap keuangan. Pengertian sikap keuangan menurut Pankow (2003) sebagaimana dikutip oleh Ningsih dan Rita (2010) sesuai pengertian yang dikembangkan oleh Klontz dkk (2011), yaitu diartikan sebagai keadaan pikiran, pendapat, serta penilaian tentang keuangan. Menurut Jodi \& Phyllis (1998) dalam Rajna et al., (2011) Sikap keuangan adalah kecenderungan psikologis yang diekspresikan ketika mengevaluasi praktik manajemen keuangan yang direkomendasikan dengan beberapa tingkatan kesepakatan dan ketidaksepakatan.

Terdapat variabel lain yang dipertimbangkan dari segi psikologis yang juga dapat mempengaruhi perilaku manajemen keuangan adalah variabel kepribadian. Menurut Sina (2014), memahami aspek kepribadian dalam mengelola keuangan dibutuhkan untuk sukses mengelola keuangan karena setiap tipe kepribadian berbeda dalam cara mengelola keuangannya. Setelah dilakukan analisis mendalam, ditemukan beberapa kelemahan dari masing-masing tipe kepribadian yang akan menyebabkan masalah keuangan seperti salah satunya adalah utang yang berlebihan. Berbagai peneliti keuangan juga menemukan bahwa aspek kepribadian juga turut mempengaruhi kesuksesan seseorang dalam mengelola keuangannya. Lown (2008) dalam Sina (2014) menemukan bahwa terjadi perbedaan kepribadian antara perempuan terkait tabungan pensiun dan juga toleransi risiko. Dipertajam lagi oleh Ika (2011) dalam Sina (2014) bahwa faktor psikologi sering dipertimbangkan sebagai kunci dalam proses keputusan keuangan. Menggunakan tipe big five ternyata mempengaruhi bagaimana membuat rencana keuangan dan juga bagaimana mengaplikasikannya dengan benar. Selanjutnya, aspek kepribadian sering mempengaruhi manajemen keuangan karena menjadi penyebab manajemen yang buruk.

Terdapat banyak UMKM yang berkembang dan maju di sentra kerajinan batik Kabupaten Bantul namun banyak pelaku UMKM yang masih belum memiliki pengetahuan keuangan dan sikap keuangan yang baik sehingga menimbulkan perilaku manajemen keuangan yang buruk. Dari latar belakang masalah di atas, peneliti tertarik untuk melakukan penelitian tentang Perilaku Manajemen Keuangan pada UMKM khususnya di Sentra Kerajinan Batik Kabupaten Bantul. Melalui penelitian ini peneliti mengangkat penelitian dengan judul "Pengaruh Pengetahuan Keuangan, Sikap Keuangan dan Kepribadian Terhadap Perilaku Manajemen Keuangan pada Pelaku UMKM di Sentra Kerajinan Batik Kabupaten Bantul". 


\section{JURNAL NOMINAL / VOLUME VII NOMOR 1 / TAHUN 2018}

\section{JENIS PENELITIAN}

Jenis Penelitian ini merupakan penelitian kausal asosiatif (causal assosiative research). Jenis penelitian asosiatif merupakan penelitian yang bersifat menanyakan hubungan antara dua variabel atau lebih (Sugiyono, 2010:57). Penelitian ini mengambil bentuk hubungan kausal, yaitu pola hubungan yang bersifat sebab akibat.

Adapun sumber data yang digunakan dalam penelitian ini adalah data primer atau data yang diperoleh secara langsung dari responden. Penelitian ini menggunakan jenis data kuantitatif karena data yang disajikan berhubungan dengan angka. Penelitian kuantitatif adalah penelitian yang menekankan pada pengujian teori-teori melalui pengukuran variabel-variabel penelitian dengan angka dan melakukan analisis data dengan prosedur statistik (Indriantoro dan Supomo, 2009: 12). Penelitian ini bertujuan untuk menguji pengaruh variabel independen (bebas) yaitu Pengetahuan Keuangan, Sikap Keuangan, dan Kepribadian terhadap variabel dependen (terikat) yaitu Perilaku Manajemen Keuangan.

\section{Perilaku Manajemen Keuangan}

Perilaku manajemen keuangan merupakan perilaku seseorang dalam mengatur keuangan mereka dari sudut pandang psikologi dan kebiasaan individu.
Perilaku manajemen ekuangan dapat juga diartikan sebagai proses pengambilan keputusan keuangan, harmonisasi motif individu dan tujuan perusahaan. Perilaku manajemen keuangan berkaitan dengan efektivitas manajemen dana, dimana arus dana harus diarahkan sesuai dengan rencana yang telah ditetapkan. Adapun indikator dalam variabel ini, yaitu jenis-jenis perencanaan dan anggaran keuangan yang dimiliki, teknik dalam menyusun perencanaan keuangan, kegiatan menabung, kegiatan asuransi, pensiun dan pengeluaran tidak terduga, kegiatan investasi, kredit/hutang, dan tagihan, monitoring pengelolaan keuangan, dan evaluasi pengelolaan keuangan.

\section{Pengetahuan Keuangan}

Pengetahuan keuangan merupakan segala sesuatu tentang keuangan yang dialami atau yang terjadi dalam kehidupan sehari-hari. Penegetahuan keuangan juga dapat didefinisikan sebagai penguasaan seseorang atas berbagai hal tentang dunia keuangan, yang terdiri dari financial tools dan financial skills. Adapun indikator dalam variabel ini, yaitu pengetahuan pengelolaan keuangan, pengetahuan tentang perencanaan keuangan, pengetahuan tentang pengeluaran dan pemasukan, pengetahuan uang dan aset, pengetahuan tentang suku bunga, pengetahuan tentang kredit, pengetahuan 
JURNAL NOMINAL / VOLUME VII NOMOR 1 / TAHUN 2018

dasar tentang asuransi, pengetahuan tentang macam-macam asuransi, pengetahuan dasar tentang investasi, pengetahuan investasi deposito, pengetahuan investasi pada saham, pengetahuan investasi pada obligasi, dan pengetahuan investasi pada properti.

\section{Sikap Keuangan}

Sikap keuangan diartikan sebagai keadaan pikiran, pendapat, serta penilaian tentang keuangan pribadinya yang diaplikasikan ke dalam sikap. Sikap keuangan didefinisikan juga sebagai penerapan prinsip-prinsip keuangan untuk menciptakan dan mempertahankan nilai melalui pengambilan keputusan dan pengelolaan sumber daya yang tepat. Adapun indikator dalam variabel ini, yaitu orientasi terhadap keuangan pribadi, filsafat utang, keamanan uang, dan menilai keuangan pribadi.

\section{Kepribadian}

Kepribadian adalah karakter yang dimiliki oleh seseorang yang terbentuk dari lingkungan. Seseorang dalam memilih karir pada dasarnya berkaitan dengan kepribadian mereka, termasuk dalam menentukan pilihan sebagai wirausaha. Sifat yang dimiliki sebagai seorang wirausaha adalah percaya diri, berorientasi pada tugas dan hasil, pengambilan risiko, kepemimpinan, keorisinilan dan berorientasi ke masa depan. Adapun indikator dalam variabel ini, yaitu percaya diri, berani mengambil risiko, kepemimpinan, berorientasi ke masa depan.

\section{HASIL PENELITIAN DAN PEMBAHASAN}

\section{Statistik Deskriptif}

Statistik Deskriptif Perilaku Manajemen Keuangan

Hasil analisis deskriptif pada variabel Perilaku Manajemen Keuangan menunjukkan bahwa skor total tertinggi yang dicapai adalah 54 dan skor terendah adalah 21. Selain itu juga diperoleh nilai Mean sebesar 35,73, Median sebesar 34,00, Modus sebesar 31,00, dan Standar Deviasi sebesar 9,36 .

\section{Statistik Deskriptif Pengetahuan}

\section{Keuangan}

Hasil analisis deskriptif pada variabel Pengetahuan Keuangan menunjukkan bahwa skor total tertinggi yang dicapai adalah 87 dan skor terendah adalah 41. Selain itu juga diperoleh nilai Mean sebesar 65,27, Median sebesar 68,00, Modus sebesar 62,00, dan Standar Deviasi sebesar 12,74.

\section{Statistik Deskriptif Sikap Keuangan}

Hasil analisis deskriptif pada variabel Sikap Keuangan menunjukkan bahwa skor total tertinggi yang dicapai adalah 31 dan skor terendah adalah 14. Selain itu juga diperoleh nilai Mean sebesar 19,97; Median sebesar 
JURNAL NOMINAL / VOLUME VII NOMOR 1 / TAHUN 2018

18,00; Modus sebesar 18,00; dan Standar Deviasi sebesar 4,69.

\section{Statistik Deskriptif Kepribadian}

Hasil analisis deskriptif pada variabel Kepribadian menunjukkan bahwa skor total tertinggi yang dicapai adalah 26 dan skor terendah adalah 9. Selain itu juga diperoleh nilai Mean sebesar 17,84; Median sebesar 18,00; Modus sebesar 17,00; dan Standar Deviasi sebesar 4,68.

\section{Hasil Pengujian Prasyarat Analisis}

\section{Uji Linearitas}

Tabel 1. Hasil Uji Linearitas

Nilai tersebut berada di atas tingkat signifikansi 0,05 sehingga dapat disimpulkan bahwa data linier.

\section{Uji Multikolinieritas}

Tabel 2. Hasil Uji Multikolinearitas

\begin{tabular}{lcc}
\hline \multicolumn{1}{c}{ Variabel } & Tolerance & VIF \\
\hline $\begin{array}{l}\text { Pegetahuan } \\
\text { Keuangan }\end{array}$ & 0,915 & 1,093 \\
\hline Sikap Keuangan & 0,850 & 1,177 \\
\hline Kepribadian & 0,924 & 1,082 \\
\hline
\end{tabular}

Hasil Uji Multikolinieritas diperoleh nilai Tolerance lebih besar dari 0,10 dan nilai Variance Inflation Factor (VIF) kurang dari 10,00. Sehingga dapat disimpulkan bahwa tidak ada korelasi antarvariabel independen atau model regresi pada penelitian ini tidak terjadi multikoliniearitas dan model regresi layak digunakan.

\section{Uji Heteroskedatisitas}

Tabel 3. Hasil Uji Heteroskedastisitas

\begin{tabular}{lc}
\hline \multicolumn{1}{c}{ Variabel } & Sig. \\
\hline Pegetahuan Keuangan & 0,161 \\
\hline Sikap Keuangan & 0,735 \\
\hline Kepribadian & 0,783 \\
\hline
\end{tabular}

Hasil uji heteroskedastisitas dengan Uji Glejser menunjukkan masing-masing variabel independen memperoleh nilai signifikansi lebih besar dari 0,05 . Sehingga dapat disimpulkan bahwa model regresi dalam penelitian ini tidak terjadi heteroskedastisitas.

\begin{tabular}{lc}
\hline \multicolumn{1}{c}{ Variabel } & Signifikansi \\
\hline Pegetahuan Keuangan & 0,247 \\
\hline Sikap Keuangan & 0,128 \\
\hline Kepribadian & 0,360 \\
\hline
\end{tabular}

Hasil Pengujian Hipotesis dan Pembahasan

\section{Uji Regresi Linear Sederhana}

Analisis regresi linier sederhana digunakan untuk mengetahui pengaruh variabel independen secara individu terhadap variabel dependen. Hasil uji regresi linier sederhana variabel independen yang terdiri dari pengetahuan keuangan, sikap keuangan, dan kepribadian secara individu terhadap perilaku manajemen keuangan adalah sebagai berikut: 
JURNAL NOMINAL / VOLUME VII NOMOR 1 / TAHUN 2018

Tabel 4. Hasil Uji Regresi Linier Sederhana

\begin{tabular}{lcc}
\hline \multicolumn{1}{c}{ Variabel } & $\boldsymbol{t}$ & Sig. \\
\hline Pengetahuan & 4,619 & 0,000 \\
Keuangan & & \\
\hline Sikap Keuangan & 3,557 & 0,001 \\
\hline Kepribadian & 2,732 & 0,010
\end{tabular}

\section{Pengaruh Pengetahuan Keuangan terhadap Perilaku Manajemen Keuangan}

Berdasarkan hasil uji signifikansi (uji statistik t) variabel pengetahuan keuangan diperoleh nilai t hitung sebesar 4,619 lebih besar dari t tabel sebesar 2,034. Sementara nilai signifikansi 0,000 lebih kecil dari 0,05. Hal ini menunjukkan bahwa pengetahuan keuangan

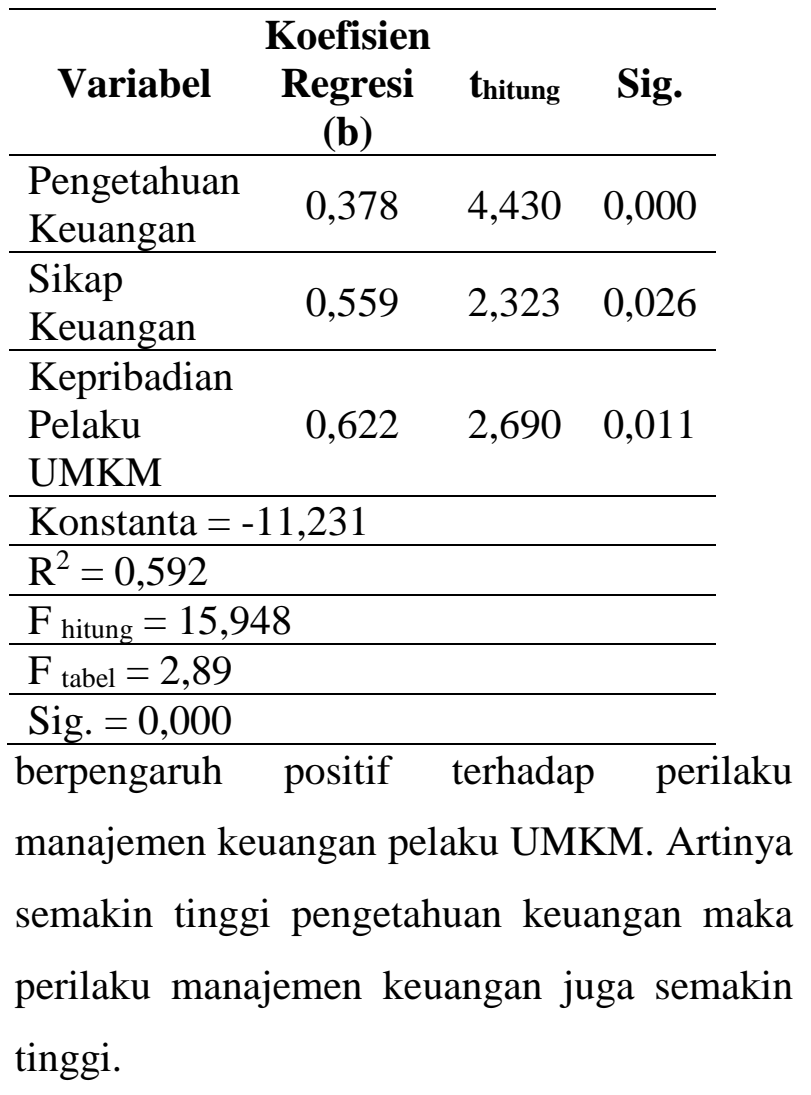

\section{Pengaruh Sikap Keuangan terhadap Perilaku Manajemen Keuangan}

Berdasarkan hasil uji signifikansi (uji statistik t) variabel sikap keuangan diperoleh nilai t hitung sebesar 3,557 lebih besar dari $\mathrm{t}$ tabel sebesar 2,034. Sementara nilai signifikansi 0,001 lebih kecil dari 0,05. Hal ini menunjukkan bahwa sikap keuangan berpengaruh positif terhadap perilaku manajemen keuangan pelaku UMKM. Artinya semakin tinggi sikap keuangan maka perilaku manajemen keuangan juga semakin tinggi.

\section{Pengaruh Kepribadian terhadap Perilaku Manajemen Keuangan}

Berdasarkan hasil uji signifikansi (uji statistik t) variabel pengetahuan keuangan diperoleh nilai t hitung sebesar 2,732 lebih besar dari t tabel sebesar 2,034. Sementara nilai signifikansi 0,010 lebih kecil dari 0,05. Hal ini menunjukkan bahwa kepribadian berpengaruh positif terhadap perilaku manajemen keuangan pelaku UMKM. Artinya semakin tinggi kepribadian maka perilaku manajemen keuangan juga semakin tinggi.

\section{Uji Regresi Linear Berganda}

Tabel 5. Hasil Uji Regresi Linier Berganda

Dari hasil pengujian diperoleh nilai

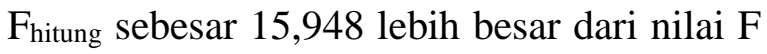
table sebesar 2,89 dengan signifikansi sebesar 0,000. Oleh karena nilai $F_{\text {hitung }}>F_{\text {tabel }}(15,948$ $>2,89$ ) dan signifikansi lebih kecil dari 0,05 


\section{JURNAL NOMINAL / VOLUME VII NOMOR 1 / TAHUN 2018}

$(0,000<0,05)$, maka dapat disimpulkan bahwa hipotesis yang menyatakan "Terdapat Pengaruh Positif Pengetahuan Keuangan, Sikap Keuangan, dan Kepribadian Secara Bersamaan terhadap Perilaku Manajemen Keuangan pada Pelaku UMKM" terbukti.

\section{SIMPULAN DAN SARAN}

\section{Simpulan}

1. Terdapat pengaruh positif Pengetahuan Keuangan terhadap Perilaku Manajemen Keuangan pada pelaku UMKM Sentra Kerajinan Batik Kabupaten Bantul. Hal ini dibuktikan dengan koefisien regresi sebesar 0,452 , nilai t hitung lebih besar dari $t$ tabel $(4,619>2,034)$, dan tingkat signifikansi lebih kecil dari 0,05 $(0,000<0,05)$.

2. Terdapat pengaruh positif Sikap Keuangan terhadap Perilaku Manajemen Keuangan pada pelaku UMKM Sentra Kerajinan Batik Kabupaten Bantul. Hal ini dibuktikan dengan koefisien regresi sebesar 1,027, nilai t hitung lebih besar dari $t$ tabel $(3,557>2,034)$, dan tingkat lebih kecil dari $0,05(0,001<0,05)$.

3. Terdapat pengaruh positif Kepribadian terhadap Perilaku Manajemen Keuangan pada pelaku UMKM Sentra Kerajinan Batik Kabupaten Bantul. Hal ini dibuktikan dengan koefisien regresi sebesar 0,838 , nilai t hitung lebih besar dari t tabel $(2,732>2,034)$, dan tingkat lebih kecil dari $0,05(0,010<0,05)$.

4. Terdapat pengaruh positif Pengetahuan Keuangan, Sikap Keuangan, dan Kepribadian terhadap Perilaku Manajemen Keuangan pada pelaku UMKM Sentra Kerajinan Batik Kabupaten Bantul. Hal ini dibuktikan dengan nilai $\mathrm{F}$ hitung $>\mathrm{F}$ tabel $(15,948>2,89)$ dengan nilai signifikansi sebesar 0,000 lebih kecil dari 0,05 $(0,000<0,05)$.

\section{Saran}

1. Berdasarkan data hasil penelitian, skor terendah pada variabel Pengetahuan Keuangan terdapat pada pernyataan "Saya mengetahui cara menyusun anggaran keuangan dan belanja". Makna hal tersebut adalah pelaku UMKM kurang mengetahui cara menyusun anggaran keuangan dan belanja, sebaiknya hal ini diperbaiki agar perilaku manajemen keuangan pelaku UMKM dapat lebih baik. Untuk memperbaiki hal tersebut pelaku UMKM dapat mengikuti seminar-seminar keuangan yang banyak diselenggarakan oleh berbagai lembaga atau mengikuti pelatihan keuangan yang biasanya diadakan oleh pemerintah. Selain itu, pelaku UMKM juga dapat mempelajari sendiri dengan membaca buku tentang 


\section{JURNAL NOMINAL / VOLUME VII NOMOR 1 / TAHUN 2018}

keuangan yang banyak dijual di toko buku atau meminjam dari perpustakaan.

2. Berdasarkan data hasil penelitian, skor terendah pada variabel Sikap Keuangan terdapat pada pernyataan "Belajar tentang keuangan menjadi prioritas". Makna hal tersebut adalah pelaku UMKM tidak menjadikan kegiatan belajar keuangan sebagai prioritas. Sebaiknya pelaku UMKM mulai menjadikan kegiatan belajar tentang keuangan sebagai prioritas, supaya perilaku manajemen keuangan pelaku UMKM dapat lebih baik.

3. Berdasarkan data hasil penelitian, skor terendah pada variabel Kepribadian terdapat pada pernyataan "Saya optimis saya bisa berhasil dalam mengelola keuangan usaha saya" Makna hal tersebut adalah pelaku UMKM kurang optimis dapat berhasil mengelola keuangan usahanya, sebaiknya hal ini diperbaiki agar perilaku manajemen keuangan pelaku UMKM dapat lebih baik. Pelaku UMKM harus merasa optimis mampu mengelola keuangan usahanya dengan baik.

4. Berdasarkan data hasil penelitian, skor terendah pada variabel Perilaku Manajemen Keuangan terdapat pada pernyataan "Menyusun anggaran pengeluaran dan belanja (harian, bulanan, tahunan). Makna hal tersebut adalah pelaku UMKM sangat jarang, bahkan ada yang tidak pernah menyusun anggaran pengeluaran dan belanja. Hal tersebut sebaiknya diperbaiki agar perilaku manajemen keuangan pelaku UMKM dapat lebih baik. Pelaku UMKM sebaiknya mulai menyusun anggaran dan tujuan keuangan hingga membuat laporan keuangan, sehingga usaha yang dijalankan akan lebih jelas arahnya.

5. Penelitian selanjutnya dapat dilakukan pada kelompok masyarakat lain dengan karakteristik yang unik dan berbeda, seperti masyarakat petani, masyarakat pada bidang eksekutif dan bisnis, dsb. Penelitian selanjutnya diharapkan mampu mempertimbangkan faktor-faktor psikologis di luar kepribadian yang bisa jadi memberikan dampak dominan dalam penerapan perilaku manajemen keuangan, seperti unsur kecerdasan spiritual, pengalaman keuangan, dan sebagainya.

\section{DAFTAR PUSTAKA}

Alma,Buchari.(2013).Kewirausahaan. Bandung: Alfabeta.

Amanah,Ersha.(2016). "Pengaruh Financial Knowledge, Financial Attitude dan External Locus of Control terhadap Personal Financial Management Behavior pada Mahasiswa S1 Universitas Telkom". Skripsi. Universitas Telkom.

Andrew,Vincentinus \& Nanik, Linawati. (2014). Hubungan Faktor Demografi dan Pengetahuan Keuangan Dengan 


\section{JURNAL NOMINAL / VOLUME VII NOMOR 1 / TAHUN 2018}

Perilaku Keuangan Karyawan Swasta di Surabaya. FINESTA.Vol. 02. No. 02.

Aprilia,Zenika.(2015). "Pengaruh Locus of Control, Financial Knowledge dan Personal Income terhadap Financial Management Behavior pada karyawan KPP Pratama Blitar". Skipsi. Universitas Negeri Malang.

Damanik,Lady Angela dan Herdjiono, Irine.(2016). Pengaruh Financial Attitude, Financial Knowledge, Parental Income Terhadap Financial Management Behavior. Jurnal Manajemen Teori dan Terapan Tahun 9. No. 3, Desember 2016.

Feist,Gregory J. (2011). Teori Kepribadian. Jakarta: Salemba Empat.

Ghozali,Imam. (2011). Aplikasi Analisis Multivariate dengan Program IBM SPSS 19. Semarang: Badan Penerbit Universitas Diponegoro.

Hadi,Sutrisno. (2004). Metodologi Research Jilid 3. Yogyakarta : Andi Offset.

Hilgert,Marianne A., Hogarth,Jeanne M., \& Beverly,Sondra G. (2003). Household financial management: The connection between knowledge and behavior. Federal Reserve Bulletin, 309-322.

Ida dan Dwinta, Chintia Yohana. (2010).Pengaruh Locus of Control, Financial Knowledge, dan Income Terhadap Financial Management Behavior. Jurnal Bisnis Dan Akuntansi. Universitas Kristen Maranatha. Vol.12, No.3, Hlm.131-144

Indriantoro,Nur dan Supomo, Bambang. (1999). Metode Penelitian Bisnis. Yogyakarta: BFE.
Jogiyanto.(2010). Analisis dan Desain Sistem Informasi, Edisi IV, Andi Offset, Yogyakarta.

Kholilah,Naila Al dan Rr.Iramani. (2013). Studi Financial Management Behavior pada Masyarakat surabaya. Journal of Business and Banking. Vol.3,No.1, Hlm.69- 80.

Kiryanto,dkk. (2000). Pengaruh Persepsi Manajer atas Informasi akuntansi Keuangan terhadap Keberhasilan Perusahaan Kecil. Simposium Nasional Akuntansi (SNA) ke III. Universitas Indonesia. Jakarta.

Lown,Jean M. (2008). The Role Of Retirement Personality Type In Motivating Women To Plan For Retirement. Research Dialogue Issue no. 93 September 2008 .

Maharani, Tarry Novita. (2016). Pengaruh Personal Financial Literacy, Financial Attitude Terhadap Financial Management Behavior Mahasiswa S1 Fakultas Ekonomi Universitas Andalas. Skripsi. Universitas Andalas.

Marsh, Brant A. (2006). Examining The Personal Finance Attitudes, Behaviors, And Knowledge Levels Of First-Year And Senior Students At BaptistUniversities In The State Of Texas. Disertasi.

Mien,Nguyen Thi Ngoc dan Thao,Tran Phuong. (2015). Factors Affecting Personal Financial Management Behaviors: Evidence from Vietnam. Proceedings of the Second Asia-Pacific Conference on Global Business, Economics, Finance and Social Sciences (AP15 Vietnam Conference) ISBN: 978-1-63415-833-6. 10-12 July, 2015.Danang-Vietnam. 


\section{JURNAL NOMINAL / VOLUME VII NOMOR 1 / TAHUN 2018}

Nababan,Darmandan Sadalia,Isfenti. (2012). Analisis Personal Financial Literacy dan Financial Behavior Mahasiswa Strata I Fakultas Ekonomi Universitas Sumatera Utara.

Ningsih,Retno Utami dan Rita,Mario Rio. (2010). Financial Attitudes dan Komunikasi Keluarga Tentang Pengeluaran Uang Saku: Ditinjau dari Perbedaan Gender. JMK. Vol.8, No.2.

Phung,Albert. (2016). Behavioral Finance: Introduction. Tersedia [Online]. http://www.investopedia.com/universit y/behavioral_finance/. Diakses pada 01 Juni 2017.

Pinasti, Margani. (2007). Pengaruh Penyelenggaraan dan Penggunaan Informasi Akuntansi terhadap Persepsi Pengusaha Kecil atas Informasi Akuntansi: Suatu Riset Eksperimen, Simposium Nasional Akuntansi (SNA) ke X, Makassar.

Rajna,A., Ezat,Sharifah W.P., Junid, Syed Al, dan Moshiri,H. (2011). Financial Management Attitude and Practice among the Medical Practitioners in Public and Private Medical Service in Malaysia. International Journal of Business and Management Vol. 6, No. 8, Hlm. 105-113.

Sekaran,Uma. (2011). Metodologi Penelitian Untuk Bisnis. (Ed.4). Jakarta: Salemba Empat.

Sina,Peter Garlans. (2014). Tipe Kepribadian dalam Personal Finance. Jurnal JIBEKA Vol.8 No.1 Hlm. 54-59.

Sjarkawi. (2008). Pembentukan Kepribadian Anak. Jakarta: Bumi Aksara.

Sony Warsono, dkk. (2010). Akuntansi UMKM. Yogyakarta. Asgard Chapter.
Sudijono, Anas. (2008). Pengantar Statistik Pendidikan. Jakarta: Rajawali pers.

Sudremi,Yuliana. (2007). Pengetahuan Sosial Ekonomi kelas X. Jakarta: Bumi Aksara.

Sugiyono. (2010). Metode Penelitian Pendidikan. Bandung: Alfabeta

Sugiyono. (2011). Metode Penelitan Kuantitatif, Kualitatif, dan R \& D. Bandung: Alfabeta

Sugiyono. (2012). Statistika untuk Penelitian. Bandung: CV Albeta.

Sukardi. (2004). Psikologi Pemilihan Karier. Jakarta: Rineka Cipta.

Syaifudin,Achmad. (2016). "Pengaruh Kepribadian, Lingkungan Keluarga, dan Pendidikan Kewirausahaan terhadap Minat Berwirausaha Mahasiswa Program Studi Akuntansi Universitas Negeri Yogyakarta". Skripsi. UNY

Wirjono,Endang Raino \& Raharjono, D.Agus Budi. (2012). Survei Pemahaman Dan Pemanfaatan Informasi Akuntansi Dalam Usaha Kecil Menengah Di Daerah Istimewa Yogyakarta. AUDI Jurnal Akuntansi dan Bisnis. Vol.7, No.2, Juli 2012.

Woodyard, A. \& Robb, C. (2012). Financial Knowledge and the Gender Gap. Journal of Financial Therapy,Vol. 3, No. 1.

Xiao, J.J, \& Dew, J. (2011). The financial management behavior scale: development and validation. Journal of Financial Counseling and Planning Education.

Yulianti,Norma dan Silvy,Meliza (2013). Sikap Pengelola Keuangan Dan 
JURNAL NOMINAL / VOLUME VII NOMOR 1 / TAHUN 2018

Perilaku Perencanaan Investasi

Keluarga di Surabaya. Journal of

Business and Banking Vol. 3 No 1, Mei

Yusuf, Syamsu. (2008). Teori Kepribadian.

Bandung: PT. Remaja Rosdakarya.

Zahroh,Fatimatus.(2014)."Menguji Tingkat

Pengetahuan Keuangan, Sikap

Keuangan, dan Perilaku Keuangan

Pribadi Mahasiswa Jurusan Manajemen

FEB semester 3 dan 7". Skipsi. UNDIP. 